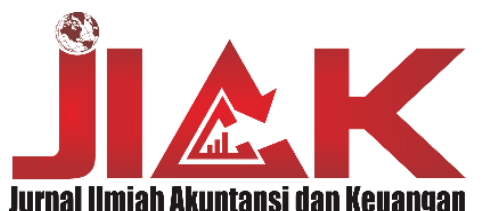

http://journal.stieputrabangsa.ac.id/index.php/jiak

ISSN: 2580-510X/ P-ISSN: 2548-9453

ARTICLE INFORMATION

Received February $9^{\text {th }} 2021$

Accepted June $12^{\text {th }} 2021$

Published June $12^{\text {st }} 2021$

DOI:

https://doi.org/10.32639/jiak. v9i2.745

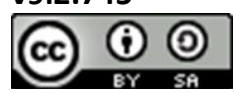

\section{Korelasi Penambahan Pasien Covid-19 Terhadap Perilaku Pasar Bursa Efek Indonesia}

\author{
Muhammad Ramdhan \\ Badan Riset Sumber Daya Manusia Kelautan dan Perikanan \\ email: ramdhanster@gmail.com
}

\begin{abstract}
ABSTRAK
Covid-19 memberikan dampak yang besar pada kehidupan masyarakat di dunia. Semua aspek kehidupan manusia terpengaruh oleh pandemi yang begitu cepat menyebar. Dalam makalah ini dibahas mengenai dampak Covid-19 terhadap sektor ekonomi di negara Indonesia. Telah dicari hubungan antara penambahan pasien positif Covid-19 dengan perilaku pasar yang digambarkan dalam fluktuasi harga di pasar saham atau lebih dikenal dengan bursa efek. Data diperoleh dari sumber yang berwenang, kemudian dianalisis menggunakan teknik statistik regresi linier sederhana. Hasilnya menunjukkan bahwa untuk skala nasional, jumlah penambahan pasien Covid-19 tidak berpengaruh signifikan terhadap bursa efek Indonesia. Sebaliknya penambahan pasien Covid-19 di ibu kota negara DKI Jakarta justru terlihat berkorelasi dengan angka Indek Harga Saham Gabungan di bursa efek Indonesia.
\end{abstract}

Kata Kunci: Covid-19; IHSG; Perilaku Pasar; Regresi Linier

\begin{abstract}
Covid-19 has had a major impact on the lives of people in the world. All aspects of human life are affected by the pandemic which is so fast spreading. This paper discusses the impact of Covid-19 on the economic sector in Indonesia. The relationship between the addition of positive Covid-19 patients and market behavior is described in price fluctuations in the stock market or better known as the stock exchange. Data obtained from authorized sources, then analyzed using simple linear regression statistical techniques. The results show that on a national scale, the number of additional Covid-19 patients has no significant effect on the Indonesian stock exchange. On the other hand, the addition of Covid-19 patients in the capital city of DKI Jakarta actually seems to be correlated with the Jakarta Composite Stock Price Index figures on the Indonesian stock exchange.
\end{abstract}

Keywords: Covid-19; JCl; Market Behavior; Linear Regression 


\section{PENDAHULUAN}

Pandemik penyakit virus korona di akhir tahun 2019 (Covid-19) telah memberikan dampak signifikan pada perilaku hidup masyarakat dunia. Covid-19 telah berdampak di bidang kesehatan manusia (Pradana et.al. 2020), di bidang lingkungan hidup (Ramdhan 2020), bidang pendidikan (Abdusshomad 2020), juga di bidang ekonomi (Yamali \& Putri 2020). Makalah ini akan membahas pengaruh Covid-19 terhadap perilaku pasar di Indonesia.

Perilaku pasar adalah tindakan yang dilakukan oleh pelaku usaha dalam kapasitasnya sebagai pemasok atau pembeli barang dan atau jasa mencapai tujuan perusahaan, antara lain pencapaian laba, pertumbuhan aset, target penjualan, dan metode persaingan yang digunakan (SEKNEG 1999). Pasar sendiri berarti lembaga ekonomi di mana para pembeli dan penjual baik secara langsung maupun tidak langsung dapat melakukan transaksi perdagangan barang dan atau jasa.

Pengertian pasar menurut konsep pemasaran berbeda dengan pengertian pasar tradisional sehari-hari. Pengertian pasar menurut pemasaran adalah kelompok individual (perorangan maupun organisasi) yang mempunyai permintaan terhadap barang tertentu, berdaya beli, dan berniat merealisasikan pembelian tersebut (Budiarto 1993). Salah satu jenis pasar adalah pasar modal, yaitu suatu pasar yang menjadi wahana investasi aset finansial berupa saham dari perusahaan yang telah go-public (Najmudin 2009). Struktur pasar modal sangat komplek, berita kejadian sehari-hari dapat mempengaruhi perilaku para pelaku pasar modal. Harga produk, dalam hal ini saham, menjadi hal yang penting untuk dipelajari. Karena harga berpengaruh terhadap perilaku pasar dan kinerja pasar (Prasetyo 2007).

Harga saham dalam pasar modal berfluktuasi sangat cepat. Ada empat momen penentuan harga yang diperhatikan oleh para pelaku pasar saham. Harga pembukaan di awal sessi hari pasar, harga penutupan di akhir sessi, harga terendah saham dan harga tertinggi saham. Para pelaku pasar akan menjadikan harga penutupan di akhir sesi sebagai patokan untuk bertransaksi di hari berikutnya. Kumpulan agregat harga saham di bursa disajikan sebagai suatu indeks yang menggambarkan indikator pergerakan harga saham. Di Indonesia indeks tersebut dikenal dengan sebutan Indeks Harga Saham Gabungan (IHSG). Tujuan penelitian ini adalah mengkaji hubungan antara penambahan jumlah pasien positif Covid-19 terhadap perilaku pasar di Indonesia yang diwakili oleh pergerakan IHSG di Bursa Efek Indonesia (BEI).

\section{METODE PENELITIAN}

Data penambahan kasus harian di Indonesia diperoleh dari website resmi Satuan Tugas Penanganan COVID-19 yaitu: https://covid19.go.id/. Data penambahan kasus covid-19 di DKI Jakarta diperoleh dari: https://riwayat-file-covid-19-dki-jakarta-jakartagis.hub.arcgis.com/. Dipilih data harian di bulan Januari 2021 untuk kemudian dilihat korelasinya terhadap perilaku pasar yang diwakili oleh harga penutupan dari BEI.

Data Indeks Harga Saham Gabungan (IHSG) Bursa Efek Indonesia diperoleh dari database ChartNexus Versi 5.0. ChartNexus adalah perangkat lunak pembuatan grafik keuangan berbasis PC (Personal Computer) yang digunakan untuk menganalisis perilaku pasar saham. ChartNexus memungkinkan penggunanya untuk memetakan tren saham berdasarkan aksi harga saham (ChartNexus 2004).

Pasar yang dalam penelitian ini diwakili oleh BEI, beraktivitas hanya pada hari kerja, hari sabtu dan minggu bursa tutup. Sehingga pada bulan Januari 2021 terdapat 20 hari pasar untuk melaksanakan aktifitas jual-beli saham. Tabel 1. Menyajikan data penambahan jumlah pasien covid-19 di Indonesia dan di wilayah DKI Jakarta, serta harga penutupan BEI. Pelaku pasar diasumsikan akan melihat data perkembangan jumlah pasien Covid-19 pada hari sebelumnya $(\mathrm{H}-1)$. 
Tabel 1. Data penambahan pasien Covid-19 dan Harga Penutupan Bursa Saham

\begin{tabular}{ccccc}
\hline $\begin{array}{c}\text { Hari Pasar } \\
\text { Ke- }\end{array}$ & Tanggal & $\begin{array}{c}\text { Penambahan H-1 } \\
(\text { IDN*) }\end{array}$ & $\begin{array}{c}\text { Penambahan H-1 } \\
(\text { JKT**) }\end{array}$ & IHSG*** \\
\hline \hline 1 & 4-Jan-21 & 6877 & 1657 & 6104 \\
2 & 5-Jan-21 & 6757 & 1832 & 6137 \\
3 & 6-Jan-21 & 7445 & 1824 & 6065 \\
4 & 7-Jan-21 & 8854 & 2402 & 6135 \\
5 & 8-Jan-21 & 9321 & 2398 & 6257 \\
6 & 11-Jan-21 & 9640 & 2711 & 6382 \\
7 & 12-Jan-21 & 8692 & 2461 & 6395 \\
8 & 13-Jan-21 & 10047 & 2669 & 6435 \\
9 & 14-Jan-21 & 11278 & 3476 & 6428 \\
10 & 15-Jan-21 & 11557 & 3165 & 6373 \\
11 & 18-Jan-21 & 11287 & 3395 & 6389 \\
12 & 19-Jan-21 & 9086 & 2361 & 6321 \\
13 & 20-Jan-21 & 10365 & 2563 & 6429 \\
14 & 21-Jan-21 & 12568 & 3786 & 6413 \\
15 & 22-Jan-21 & 11703 & 3151 & 6307 \\
16 & 25-Jan-21 & 11788 & 3512 & 6258 \\
17 & 26-Jan-21 & 9994 & 2451 & 6140 \\
18 & 27-Jan-21 & 13094 & 2314 & 6109 \\
19 & 28-Jan-21 & 11948 & 1836 & 5979 \\
20 & 29-Jan-21 & 13695 & 2889 & 5862 \\
\hline
\end{tabular}

Ket: *Indonesia, ** Jakarta, *** Indeks Harga Saham Gabungan

Selanjutnya korelasi antara penambahan jumlah pasien positif Covid-19 dengan Indeks Harga Saham Gabungan akan dimodelkan menggunakkan analisis regresi linier sederhana. Regresi linier sederhana merupakan bentuk hubungan di mana variabel bebas $X$ maupun variabel tergantung $Y$ sebagai faktor yang berpangkat satu (Syafruddin et.al. 2014). Bentuk fungsi dari regresi linier sederhana adalah sebagai berikut:

$$
Y=a+b X
$$

Analisis regresi banyak diterapkan dalam penelitian statiskita. Berikut adalah tiga aplikasi penggunaan regresi linier: Pertama regresi digunakan untuk mendeskripsikan fenomena data melalui terbentuknya suatu model hubungan yang bersifatnya numerik. Kedua regresi juga dapat digunakan untuk melakukan pengendalian (kontrol) terhadap suatu kasus atau hal-hal yang sedang diamati melalui penggunaan model regresi yang diperoleh. Ketiga, model regresi dapat dimanfaatkan untuk melakukan prediksi untuk variabel terikat (Kurtner et.al. 2004). Dalam penelitian ini analisi regresi dimanfaatkan untuk menjelaskan/mendeskripsikan hubungan antara penambahan pasien Covid-19 dengan Indeks Harga Saham Gabungan di Indonesia.

Untuk menguji model yang akan digunakan apakah ada hubungan dengan parameter yang digunakan maka dilakukan beberapa tes, yaitu: Pertama, uji Test Koefisien Penentu $\left(R^{2}\right)$, pengetesan ini untuk mengetahui tepat tidaknya varibel yang mempengaruhi (jumlah penambahan pasien Covid-19) terhadap besarnya variabel yang diramalkan (IHSG). Kedua, Uji simultan model regresi yaitu pengetesan untuk mengetahui apakah benar persamaan regresi itu adalah linier melalui nilai $\mathrm{P}$ ( $p$-value).

P-value dapat pula diartikan sebagai besarnya peluang melakukan kesalahan apabila kita memutuskan untuk menolak hipotesis awal awal $\left(\mathrm{H}_{0}\right)$. Pada umumnya, $\mathrm{p}$-value dibandingkan dengan suatu taraf nyata $\alpha$ tertentu, biasanya 0.05 atau $5 \%$. Taraf nyata $\alpha$ diartikan sebagai peluang kita melakukan kesalahan untuk menyimpulkan bahwa $\mathrm{H}_{0}$ salah, padahal sebenarnya statement $\mathrm{H}_{0}$ yang benar. Kesalahan semacam ini biasa dikenal dengan galat/kesalahan jenis I (type I error, baca = type one error). 
Misal $\alpha$ yang digunakan adalah 0.05, jika $p$-value sebesar $0.021(<0.05)$, maka kita berani memutuskan menolak $\mathrm{H}_{0}$. Hal ini disebabkan karena jika kita memutuskan menolak $\mathrm{H}_{0}$ (menganggap statement $\mathrm{H}_{0}$ salah), kemungkinan kita melakukan kesalahan masih lebih kecil daripada $\alpha=0.05$, dimana 0.05 merupakan ambang batas maksimal dimungkinkannya kesalahan dalam membuat keputusan (Kurniawan 2008). Dalam penelitian ini $\mathrm{H}_{0}$ adalah tidak adanya hubungan antara penambahan kasus positif Covid-19 dengan pergerakan nilai IHSG.

\section{HASIL DAN PEMBAHASAN}

\section{Penambahan Pasien Positif Covid-19}

Covid-19 mulai muncul di Indonesia pada akhir bulan Februari 2020 (Ramdhan, 2020). Pada akhir bulan Januari 2021, total angka kasus di Indonesia telah menembus angka satu juta orang positif terkena virus penyebab Covid-19. Menurut situs https://www.worldometers.info/, Indonesia pada bulan Februari 2021 berada di peringkat ke 19 dunia jumlah kemunculan kasus Covid-19. Di kawasan Asia Tenggara, Indonesia adalah negara peringkat 1 terbanyak jumlah kasus Covid-19. Hal ini menggambarkan bahwa penyebaran Covid-19 di Indonesia belum dapat dikendalikan dengan baik.

Pada Gambar 1, telihat bahwa Covid-19 banyak terjadi di kota-kota besar di Indonesia seperti: Jakarta, Medan, Pekanbaru, Denpasar, Balikpapan, Makassar, Ambon, Sorong. Hal ini logis, karena kota merupakan pusat perekonomian. Aktivitas ekonomi membuat banyak terjadinya kerumunan, sehingga virus Covid-19 dapat menular secara cepat. Bagi para pelaku pasar bursa saham, yang umumnya tergolong dalam kelompok masyarakat berpendidikan menengah keatas (katadata.co.id), kondisi penambahan kasus Covid-19 yang belum terkendali menjadi pertimbangan para investor bursa saham dalam melakukan transaksi.

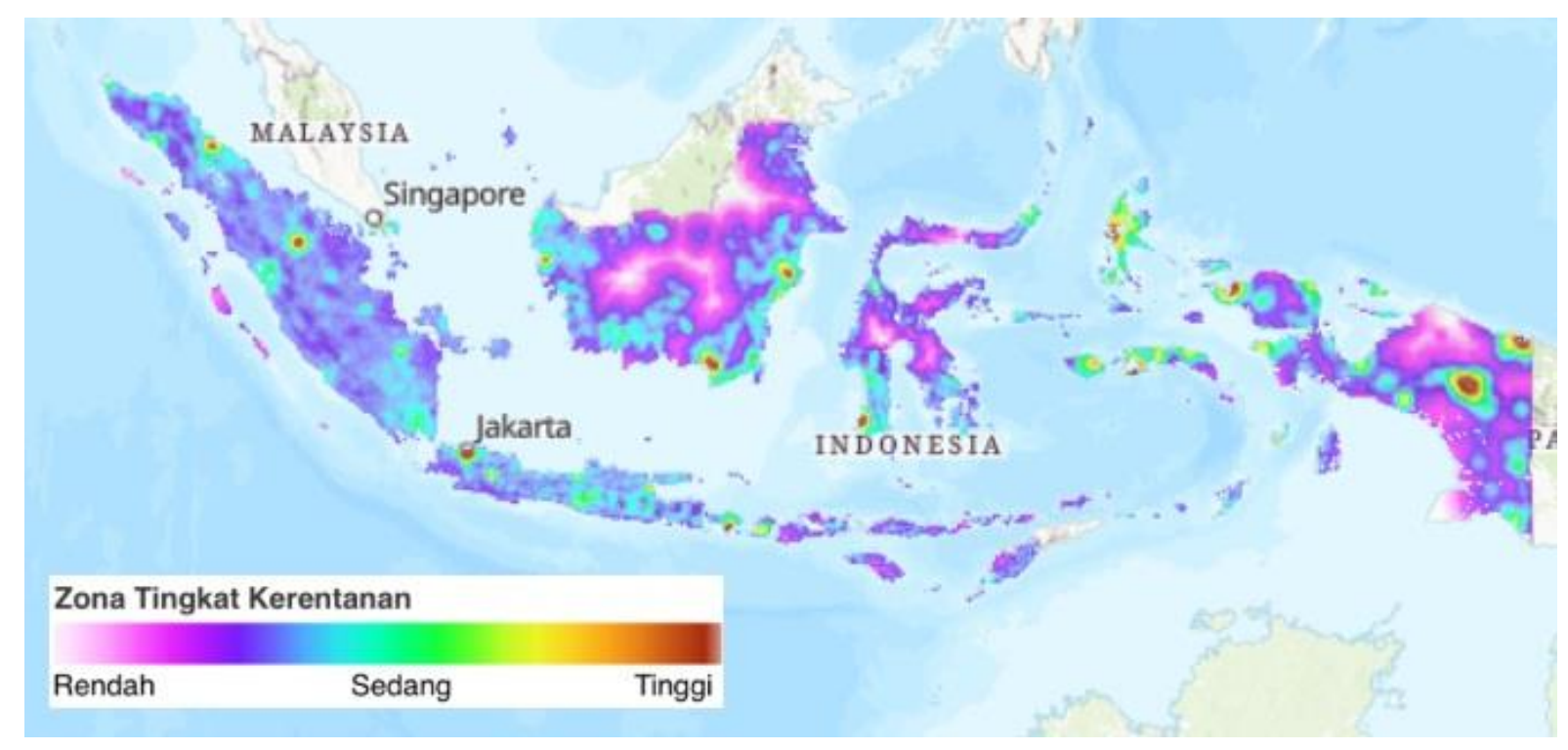

Gambar 1. Peta Tingkat Kerentanan Penyebaran Penyakit Covid-19 di Indonesia

(Sumber: https://covid19.lapan.go.id/pages/indonesia)

\section{Analisis IHSG Setelah Pandemi Covid-19}

Semenjak pandemi Covid-19 melanda dunia, IHSG berada dalam tren penurunan karena dipengaruhi sentimen negatif dari virus Corona yang menyebar begitu cepat di China. Sebagai negara dengan ekonomi yang cukup besar, China tentunya memberikan pengaruh signifikan atas ekonomi dunia. 
Perkembangan pasar modal Indonesia saat ini bergejolak semenjak Pandemi Covid-19. Melihat situasi perekonomian Indonesia sangat memprihatikan yang menyebabkan koreksi cukup dalam di pasar modal Indonesia. Indeks harga saham gabungan telah turun $22 \%$ di awal tahun 2020. Pasar modal Indonesia menjadi salah satu negara yang mengalami penurunan yang cukup drastis. Berdasarkan data yang di dapat mulai dari infrastuktur, pertanian, aneka industri, pertambangan dan yang lainnya sudah mulai melemah sedangkan sektor keuangan mengalami peningkatan.

Dampak Pandemi Covid-19 menyebabkan penghambatan aktivitas ekonomi dan perdagangan. Di tengah kondisi Pandemi Covid-19, Otoritas Jasa Keuangan tidak hanya berdiam diri dan terus memantau perkembangan pasar modal di Indonesia untuk menjaga agar pasar tetap beroperasi. Bersama dengan Self-Regulatory Organization, Otoritas Jasa Keuangan terus mengupayakan berlangsungnya aktivitas perdagangan secara efisien, teratur dan layanan untuk seluruh stakeholders. Untuk kelangsungan operasional atau aktivitas pasar, Otoritas Jasa Keuangan dan Self-Regulatory Organization telah melakukan Business Continuity Management untuk tercapainya hal tersebut. Bursa Efek Indonesia juga sudah menyiapkan solusi untuk melakukan relaksasi agar pasar tetap menjanjikan.

Sesuai dengan surat keputusan direksi PT. Bursa Efek Indonesia dengan nomor Kep-0003 I/BEI/03-2020 perihal Perubahan Waktu Perdagangan atas Transaksi Bursa bahwa berkenaan dengan perkembangan kondisi pasar modal global maupun pasar modal Indonesia sedang mengalami tekanan yang antara lain dipengaruhi penetapan virus corona (Covid-19) sebagai pandemi global oleh World Health Organization (BEI, 2020), perlu diambil langkahlangkah untuk mengurangi tekanan kepada pasar modal Indonesia. Dalam rangka menjaga stabilitas Pasar Modal, serta sesuai dengan arahan Presiden Republik Indonesia untuk mendukung penerapan Working from Home untuk meminimalisasi penyebaran Covid-19 perlu diambil langkah langkah tambahan untuk menjaga keberlangsungan pasar modal agar tetap kondusif, bahwa Bursa telah menetapkan waktu perdagangan, batas waktu penyampaian laporan pesanan titipan, batas waktu penyampaian permohonan koreksi Transaksi Bursa dan waktu penerbitan Weighted Moving Average Price dalam Peraturan Bursa. Waktu perdagangan di Pasar Reguler hari Senin sampai dengan Jumat dilakukan dengan ketentuan sebagai berikut:

1. Sesi I pukul 09.00.00 sampai dengan 11.30.00 digunakan oleh Anggota Bursa Efek untuk memasukkan penawaran jual dan/atau permintaan beli, dan JATS (Jakarta Automated Trading System) memperjumpakan secara berkelanjutan atas penawaran jual dengan permiotaan beli untuk Efek yang sama secara keseluruhan maupun sebagian berdasarkan prioritas harga dan waktu.

2. Sesi II pukul 13.30.00 sampai dengao 14.49.59 digunakan oleh Anggota Bursa Efek untuk memasukkan penawaran jual dan/alau permintaan beli, dan JATS memperjumpakan secara berkelanjutan atas penawaran jual dengan permintaan beli untuk Efek yang sama secara keseluruhan maupun sebagian berdasarkan prioritas harga dan waktu.

Sesi Pra-penutupan, yaitu:

1. Pukul 14.50 .00 sampai dengan 15.00 .00 digunakan oleh Anggota Bursa Efek untuk memasukkan penawaran jual dan/atau permintaan beli.

2. Pukul 15.00.01 sampai dengau 15.04.59 JATS melakukan proses pembentukan harga penutupan dan memperjumpakan penawaran jual dengan permintaan beli pada harga penutupan berdasarkan prioritas harga dan waktu.

3. Sesi Pasca Penutupan pukul 15.05 sampai dengan pukul 15.15 .00 digunakan oleh Anggota Bursa Efek untuk memasukkan penawaran jual dan/atau permiutaan beli pada harga penutupan, dan JATS memperjumpakan secara berkelanjutan atas penawaran jual dengan permintaan beli untuk Efek yang sama secara keseluruhan maupun sebagian pada harga penutupan berdasarkan prioritas waktu.

Berdasarkan perubahan waktu bursa tersebut, terdapat kecenderungan investor mengelola kembali portofolio investasi yang dimilikinya. Dengan perubahan waktu yang dikurangi, kondisi tersebut bisa menyebabkan penurunan maupun kenaikan transaksi jual beli saham. Suatu pasar bereaksi terhadap informasi merupakan hal yang sangat penting karena dapat mengakibatkan perubahan harga yang 
membuat abnormal return berubah serta perubahan persepsi investor untuk mengambil keputusan investasi.

Pemerintah mengumumkan secara resmi kasus positif pertama Covid-19 di Indonesia pada awal Maret 2020 yang terdiri dari 2 orang. Pada hari itu IHSG ditutup turun 91 poin $(1,67 \%)$ ke level 5.361. Pandemi Covid-19 telah membawa situasi abnormal pada bursa saham (Kusnandar dan Bintari, 2020). Faktor yang mempengaruhi investor masuk bursa diantaranya adalah aktivitas pasar, aksi korporasi, imbal hasil, pembatasan risiko, kinerja perusahaan, perkembangan bisnis, dan saham pilihan. Faktor dominan yang paling berpengaruh dalam beli dan jual saham di BEl adalah aktivitas pasar (Dewi 2018). Pandemi Covid-19 ini menjadikan aktifitas pergerakan manusia terbatas. Namun untuk transaksi secara online di pasar saham tidak mengalami kendala.

Tabel 2. Volume perdagangan di BEI pada tahun 2019-2020

\begin{tabular}{cccc}
\hline Tahun & $\begin{array}{c}\text { Harga } \\
\text { Penutupan }\end{array}$ & $\begin{array}{c}\text { Volume } \\
\text { perdagangan rata- } \\
\text { rata harian }\end{array}$ & $\begin{array}{c}\text { Frekuensi } \\
\text { Perdagangan } \\
\text { harian }\end{array}$ \\
\hline \hline 2019 & 6299 & 14540 & 468804 \\
2020 & 5979 & 11374 & 677430 \\
\hline
\end{tabular}

Sumber : IDX, 2020

Pada tabel 2. terlihat bahwa perdagangan di BEI mengalami penurunan dari tahun 2019 sebelum pandemi Covid-19 yang ditutup dengan harga IHSG Rp. 6299, menjadi Rp.5979 pada penutupan di tahun 2020 (setelah pandemi Covid-19). Volume perdagangan juga mengalami penurunan, meskipun frekuensi perdagangannya mengalami kenaikan. Frekuensi perdagangan naik dikarenakan setelah pandemi Covid19 banyak investor baru yang masuk ke bursa saham. Investor baru tersebut melihat peluang menjadikan bursa saham sebagai alternatif mencari penghasilan yang praktis di masa pandemi. Karena adanya layanan transaksi on-line yang memudahkan para investor untuk bertransaksi dari rumah.

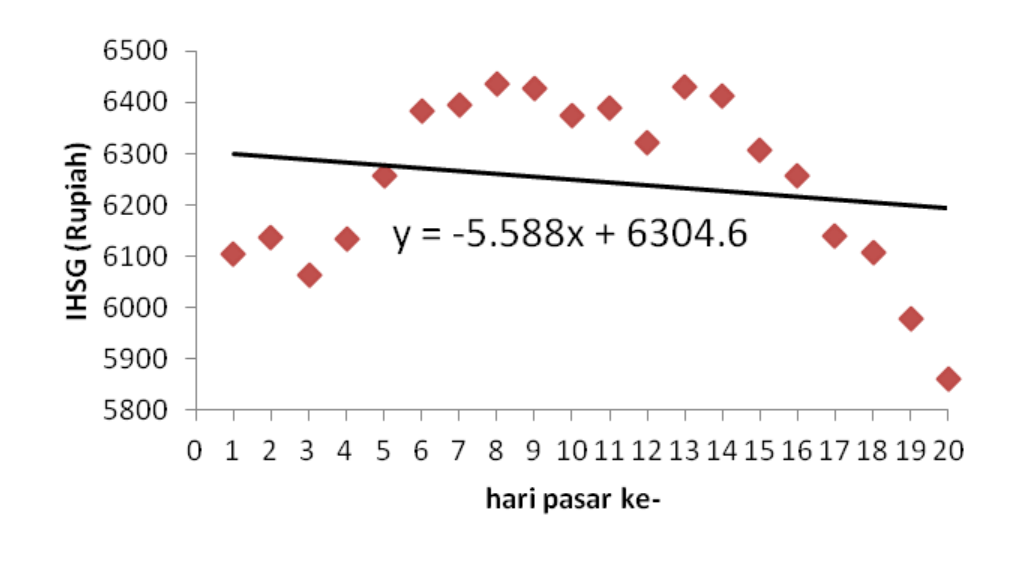

Gambar 2. Tren Nilai IHSG di Bulan Januai 2021

Dari Gambar 2, terlihat bahwa di bulan Januari 2021 Bursa Efek Indonesia mengalami tren penurunan nilai IHSG. Pada awal bulan nilai IHSG berada di angka Rp. 6104, menyentuh angka tertinggi di hari ke-8 dengan angka Rp. 6435, di akhir bulan menyentuh nilai terendah Rp. 5862.

\section{Korelasi nilai IHSG dengan kasus Covid-19}

Hipotesis awal $\left(\mathrm{H}_{0}\right)$ yang digunakan dalam penelitian ini adalah tidak ada korelasi atau hubungan antara pertambahan jumlah pasien positif Covid-19 dengan nilai IHSG di bursa saham Indonesia. Hipotesis tersebut akan diuji menggunakan software minitab ver. 1.6. untuk dilihat apakah dapat diterima atau tidak. Selanjutnya dengan software yang sama akan dilihat sebesar apa korelasi yang bisa dijelaskan melalui persamaan regresi linier sederhana. 


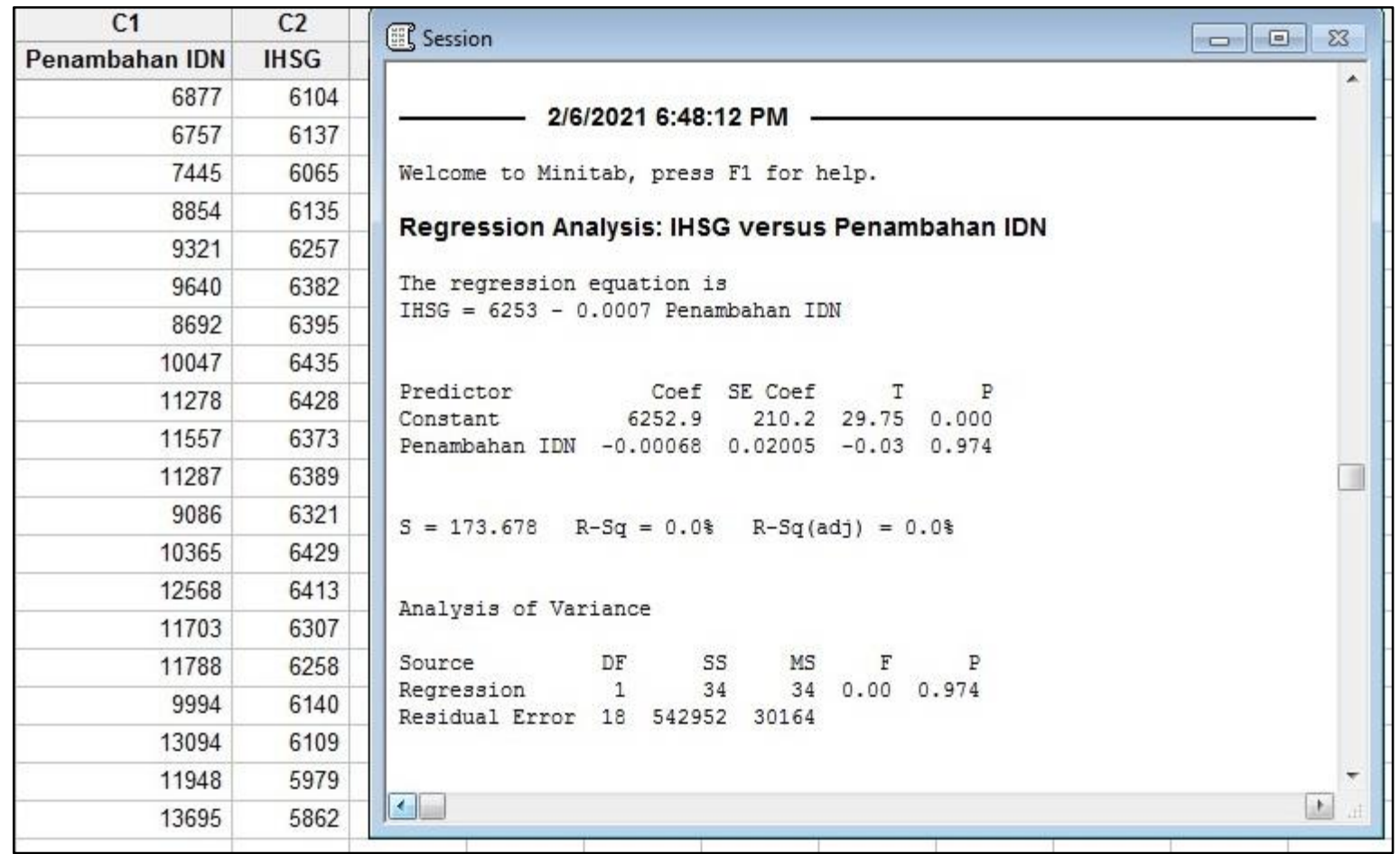

Gambar 3. Hasil regresi linier minitab IHSG vs penambahan pasien Covid-19 di Indonesia

Gambar 3. Menunjukkan hasil pengolahan data untuk korelasi antara penambahan pasien Covid-19 di tingkat nasional dengan nilai IHSG. Berdasarkan hasil perhitungan statistik, pada kasus nasional $H_{\circ}$ diterima karena $\mathrm{p}>0.05$ menunjukkan bahwa tidak ada korelasi antara pertambahan pasien positif covid-19 di Indonesia dengan pergerakan IHSG.

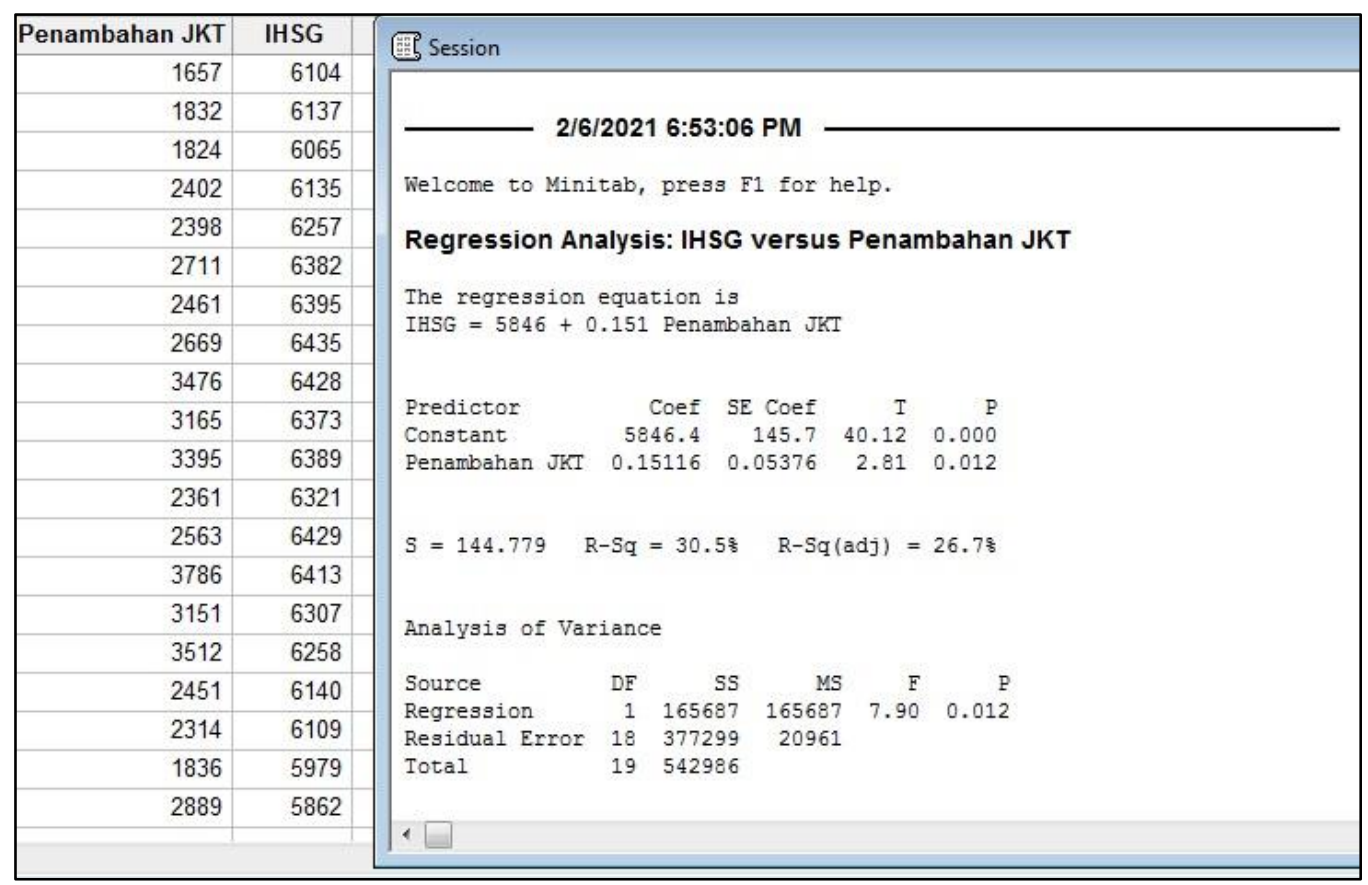

Gambar 4. Hasil regresi linier minitab IHSG vs penambahan pasien Covid-19 di Jakarta 
Gambar 4. Adalah hasil pengolahan data software minitab terhadap korelasi antara penambahan pasien covid-19 di tingkat provinsi DKI Jakarta dengan nilai IHSG. Berdasarkan perhitungan statistik, pada kasus ini $\mathrm{H}_{0}$ ditolak karena $\mathrm{p}<0.05$ yaitu 0.012 dengan nilai $\mathrm{R}^{2}=30.5 \%$. Hal ini berarti ada korelasi antara pertambahan jumlah pasien covid-19 di DKI Jakarta dengan pergerakan nilai IHSG. Adapun nilai $\mathrm{R}^{2}$ menunjukkan bahwa penambahan pasien Covid-19 tersebut hanya menjelaskan $30.5 \%$ saja dari pergerakan IHSG. Adapun persamaan regressi yang terbentuk adalah IHSG $=5864+0,151$ Penambahan JKT, hal ini menunjukkan bahwa penambahan positif Covid-19 di Jakarta akan menyebabkan IHSG bergerak naik.

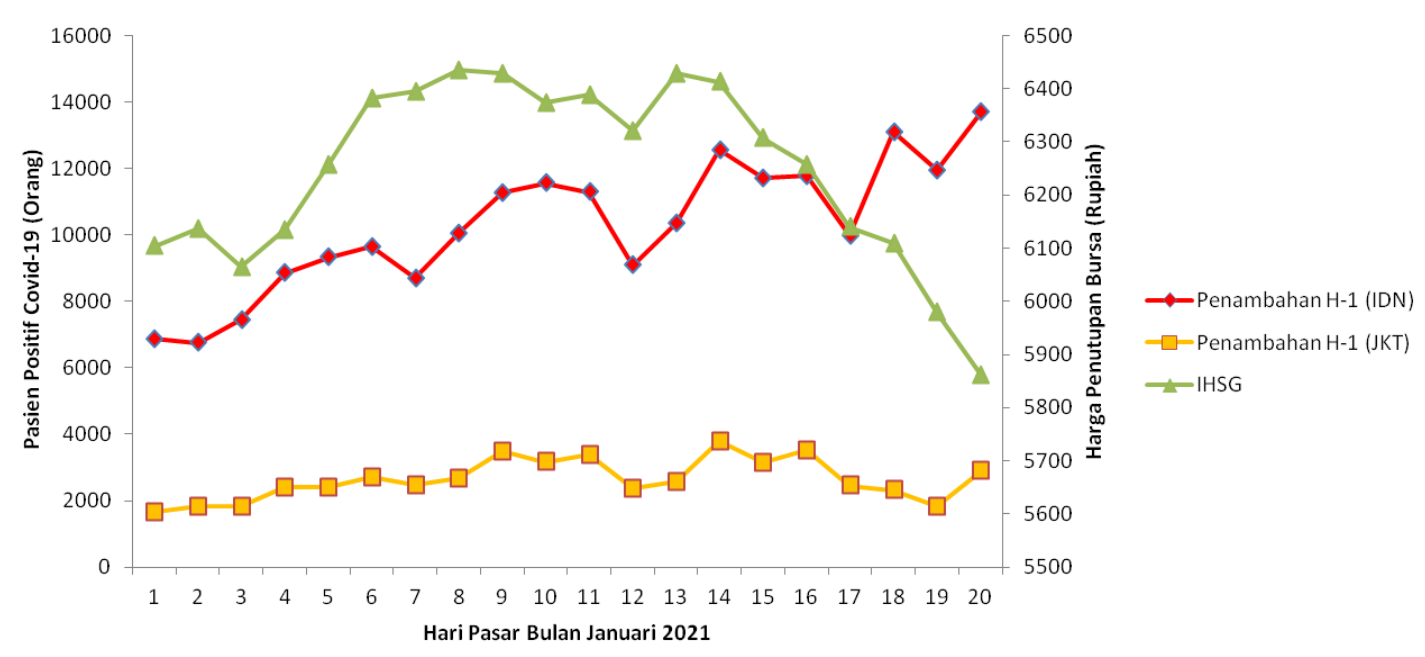

Gambar 5. Grafik penambahan Covid-19 di Indonesia dan di DKI Jakarta disandingkan dengan Grafik IHSG

Secara visual pada grafik Gambar 5. dapat diperoleh informasi bahwa pada hari pasar ke-1 hingga hari pasar ke-16 pergerakan IHSG pada bulan Januri 2021 relatif sama dengan pergerakan jumlah pasien Covid-19 di tingkat Nasional maupun di tingkat provinsi DKI Jakarta. Pada hari pasar ke-17 hingga ke-20 nilai IHSG mengalami penurunan yang signifikan, kebalikannya untuk penambahan pasien Covid-19 di tingkat nasional mengalami lonjakan yang cukup tinggi, sedangkan di tingkat DKI Jakarta penambahannya relatif stagnan.

\section{SIMPULAN}

Pandemi covid-19 telah memberikan dampak di berbagai sektor kehidupan. Salah satu sektor yang terdampak langsung adalah sektor ekonomi. Penelitian ini telah melakukan analisis korelasi dari penambahan pasien Covid-19 terhadap perilaku pasar Bursa Efek Indonesia. Perilaku pasar diwakili oleh pergerakan nilai Indeks Harga Saham Gabungan yang terjadi di Bursa Efek Indonesia pada bulan Januari 2021.

Pada skala nasional, jumlah penambahan pasien Covid-19 tidak berpengaruh signifikan terhadap bursa efek Indonesia. Hal ini dibuktikan dengan nilai $p$-value yang melebihi 0.05 . Sebaliknya penambahan pasien Covid-19 di ibu kota negara DKI Jakarta justru terlihat berkorelasi dengan angka Indek Harga Saham Gabungan di bursa efek Indonesia. Namun korelasi ini hanya bisa menjelaskan $30.5 \%$ dari pergerakan harga saham yang terjadi di lantai Bursa Efek Indonesia, sehingga dapat disimpulkan bahwa penambahan pasien Covid-19 tidak terlalu berdampak signifikan pada perilaku pasar di Indonesia. 


\section{REFERENSI}

Abdi, M. N. (2020). Krisis Ekonomi Global dari Dampak Penyebaran Virus Corona (Covid-19). AkMen Jurnal Ilmiah, 17(1), 90-98.

Abdusshomad, A. (2020). Pengaruh Covid-19 terhadap Penerapan Pendidikan Karakter dan Pendidikan Islam. QALAMUNA: Jurnal Pendidikan, Sosial, dan Agama, 12(2), 107-115.

Aldin, I. U. (2020). BEl: Tahun Ini Awal Kebangkitan Investor Retail di Pasar Modal. https://katadata.co.id/safrezifitra/finansial/5fc64398c3124/bei-tahun-ini-awal-kebangkitaninvestor-retail-di-pasar-modal, diakses pada tanggal 08 Februari 2021

Budiarto, T. (1993). Dasar Pemasaran. Jakarta: Universitas Gunadarma.

ChartNexus (2004), Manual Software. https://www.chartnexus.com/learning/manual/cnx/sect0001. diakses pada tanggal 04 Februari 2021

Dewi, F. R. (2018) Faktor-Faktor yang Mempengaruhi Investor dalam Beli dan Jual Saham di Bursa Efek Indonesia. Skripsi. Sekolah Bisnis, Institut Pertanian Bogor.

IDX (2020). IDX Annually Statistics 2020, Indonesia Stock Exchange. Jakarta: Data Service Division.

Kusnandar, D. L., \& Bintari, V. I. (2020). Perbandingan Abnormal Return Saham Sebelum dan Sesudah Perubahan Waktu Perdagangan Selama Pandemi Covid-19. Jurnal Pasar Modal dan Bisnis, 2(2), 195-202.

Kutner, M. H., Nachtsheim, C. J., \& Neter, J. (2004) Applied Linear Regression Models, Fourth Ed. New York: The McGraw-Hill Company Inc.

Najmudin, N. (2018). Eksistensi Profitabilitas Strategi Investasi Momentum di Bursa Efek Indonesia. Performance: Jurnal Personalia, Financial, Operasional, Marketing dan Sistem Informasi, 9(2), 1-20.

Pradana, A. A., \& Casman, C. (2020). Pengaruh Kebijakan Social Distancing pada Wabah COVID-19 terhadap Kelompok Rentan di Indonesia. Jurnal Kebijakan Kesehatan Indonesia: JKKI, 9(2), 61-67.

Prasetyo, P. E. (2007). Hubungan Struktur Pasar dan Perilaku Pasar Serta Pengaruhnya Terhadap Kinerja Pasar. Economic Journal of Emerging Markets, 12(2).

Ramdhan, M. (2020). Pengaruh Pandemik Covid-19 Terhadap Tutupan Vegetasi di DKI Jakarta. Jurnal Riset Jakarta, 13(2), 49-54.

SEKNEG (1999) Undang-Undang Republik Indonesia Nomor 5 Tahun 1999 Tentang Larangan Praktek Monopoli dan Persaingan Usaha Tidak Sehat, Lembaran Negara Republik Indonesia Tahun 1999 Nomor 33, Sekretariat Negara Republik Indonesia, Jakarta, $50 \mathrm{hlm}$.

Surat Keputusan Direksi PT Bursa Efek Indonesia tentang Perubahan Waktu Perdagangan atas Transaksi Bursa Penyelenggaraan Kegiatan di Bidang Pasar Modal, https://covid19. hukumonline.com/wpcontent/uploads/2020/04/keputusan_direksi_pt_bursa_efek indonesia_n omor kep 00032 bei 032020 tahun 2020-2.pdf, diunduh pada tanggal 07 Februari 2021

Syafruddin, M. L. H. D. D., Hakim, L., \& Despa, D. (2014). Metode Regresi Linier Untuk Prediksi Kebutuhan Energi Listrik Jangka Panjang (Studi Kasus Provinsi Lampung). Jurnal Informatika dan Teknik Elektro Terapan, 2(2), 51-60.

Yamali, F. R., \& Putri, R. N. (2020). Dampak Covid-19 Terhadap Ekonomi Indonesia. Ekonomis: Journal of Economics and Business, 4(2), 384-388. 